\title{
Nukleærmedisinsk utredning av pasienter med hjertesvikt
}

\begin{abstract}
Sammendrag
Bakgrunn. Resynkroniseringsterapi med biventrikulær pacemaker er nylig blitt implementert som en del av behandlingen ved alvorlig hjertesvikt. Ved bruk av de klassiske inklusjonskriteriene for resynkroniseringsterapi er det $30 \%$ som ikke viser bedring etter behandling. Ved hjelp av en nukleærmedisinsk metode, faseanalyse av isotopventrikulografi, kan man beregne veggbevegelsen i små segmenter av ventriklene og slik detektere dyssynkrone bevegelser. Metoden vil derfor kunne være anvendbar for å selektere pasienter med dyssynkronitet til resynkroniseringsterapi. I denne artikkelen har vi sett på sammenhengen mellom venstre ventrikkels ejeksjonsfraksjon og dyssynkronitet vurdert ut fra faseanalyse av isotopventrikulografi.
\end{abstract}

Materiale og metode. Studien er basert på en retrospektiv gjennomgang av 1266 isotopventrikulografier utført ved Nukleærmedisinsk seksjon ved Universitetssykehuset Nord-Norge i perioden 1998-2006. Vi har sett på sammenhengen mellom venstre ventrikkels ejeksjonsfraksjon og grad av ventrikulær dyssynkronitet. Referanseverdier for synkronitet ble beregnet fra en populasjon på 90 pasienter uten kjent hjertesykdom.

Resultater. For pasienter med venstre ventrikkels ejeksjonsfraksjon under $35 \%$ avdekket faseanalysen at det hos $35 \%$ av kvinnene og $34 \%$ av mennene var både inter- og intraventrikulær dyssynkronitet.

Fortolkning. Dagens inklusjonskriterier for resynkroniseringsterapi er ikke gode nok. Bruk av faseanalyse av isotopventrikulografier viser at en tredel av dem med venstre ventrikkels ejeksjonsfraksjon under $35 \%$ har både inter- og intraventrikulær dyssynkronitet. Disse pasientene vil muligens ha nytte av resynkroniseringsterapi.

\author{
Ingebjørg Larsen \\ Hanne Marie Weydahl \\ Det medisinske fakultet \\ Universitetet i Tromsø \\ Seksjon for nukleærmedisin \\ Universitetssykehuset Nord-Norge \\ Erik R. Traasdahl \\ Rune Sundset \\ rune.sundset@unn.no \\ Avdeling for radiologi og nukleærmedisin \\ Seksjon for nukleærmedisin \\ Universitetssykehuset Nord-Norge \\ 9038 Tromsø
}

Hjertesviktpasienter med dyssynkronitet kan ha nytte av resynkroniseringsterapi i form av stimulering fra biventrikulær pacemaker. Resynkroniseringsterapi gjennomføres ved å plassere én elektrode i høyre atrium og én i høyre ventrikkel, der begge stimulerer endokard. Den tredje elektroden føres inn i koronar sinus over venstre ventrikkel og stimulerer venstre ventrikkels epikard til tidlig aktivering og dermed resynkronisering av septum samt venstre ventrikkels frie vegg. Resultatene av CARE-HF-studien (1, 2), med en oppfølgingstid på gjennomsnittlig 37,4 måneder, viser redusert risiko for morbiditet $(45 \%)$ og mortalitet $(40 \%)$ for dem som får resynkroniseringsterapi sammenliknet med dem som får optimal medikamentell behandling.

Ved bruk av alle de tre klassiske inklusjonskriteriene for resynkroniseringsterapi (tab 1) er det $30 \%$ av pasientene som ikke viser bedring i NYHA-funksjonsklasse (3). Årsaken til det lave antall med respons kan skyldes at dagens inklusjonskriterier ikke er gode nok eller at implanteringen av elektrodene er suboptimal. Ved hjelp av en nukleærmedisinsk metode (faseanalyse av isotopventrikulografi) kan man beregne små veggsegmenters bevegelsesfase. Dette kan være en måte å øke presisjonen i seleksjon av pasienter som trenger resynkroniseringsterapi og slik få en større andel respondere. Vi kjenner ikke til at metoden er blitt brukt i Norge, og det er begrenset internasjonal litteratur om bruk av faseanalyse for å velge ut pasienter til behandling med biventrikulær pacemaker (4-6). I denne studien har vi beregnet referanseverdier for synkronitet med bakgrunn i en normalfordeling. Vi har undersøkt sammenhengen mellom grad av dyssynkrone veggbevegelser og venstre ventrikkels ejeksjonsfraksjon (LVEF) samt andelen kvinner og menn med dyssynkronitet som funksjon av venstre ventrikkels ejeksjonsfraksjon.
Tabell 1 Klassiske inklusjonskriterier for resynkroniseringsterapi

$\begin{array}{lc}\text { QRS-bredde } & \geq 120 \mathrm{~ms} \\ \begin{array}{l}\text { Venstre ventrikkels ejek- } \\ \text { sjonsfraksjon }\end{array} & \leq 35 \% \\ \text { NYHA-klasse } & \text { III eller IV }\end{array}$

\section{Materiale og metode}

Ved Seksjon for nukleærmedisin, Universitetssykehuset Nord-Norge, har man i perioden 1998-2006 utført om lag 1500 isotopventrikulografier for bestemmelse av venstre ventrikkels ejeksjonsfraksjon. Ved denne undersøkelsen merkes erytrocyttene med technetium. Isotopen fordeler seg jevnt $\mathrm{i}$ blodbanen og avbildes ved hjelp av gammakamera (blood pool scintigrafi). Normalt vil ejeksjonsfraksjonen være 55-80\% ved denne undersøkelsen. Ved hjertesvikt faller den. Ved undersøkelsen kan man i tillegg til ejeksjonsfraksjonsbestemmelser få frem bilder som viser ventrikkelveggens bevegelighet som følge av endring i ventriklenes blodvolum. Et såkalt fasebilde fremstilles ved hjelp av et kommersielt tilgjengelig dataprogram (XT ERNA, GE Medical Systems Europe, Frankrike) og er vist i figur 1.

Endringen i fargeintensitet for hver piksel i bildet som funksjon av tiden gjenspeiler volumendringen i gitte piksel. Hver piksel i bildet gjennomgår en matematisk manipulering (Fourier-transformasjon), der intensitetsendringen i tid tilpasses en cosinuskurve (fig 1b) med R-takken i pasientens EKG

\section{Hovedbudskap}

- Mange pasienter med alvorlig hjertesvikt har dyssynkrone ventrikkelveggbevegelser og kan ha nytte av resynkroniseringsterapi

- Ved bruk av klassiske inklusjonskriterier for resynkroniseringsterapi er det $30 \%$ som ikke responderer

- Vår studie viser at 35 \% av kvinnene og $34 \%$ av mennene med venstre ventrikkels ejeksjonsfraksjon < $35 \%$ har intraog interventrikulær dyssynkronitet

- Isotopventrikulografi med faseanalyse kan være egnet for å identifisere dem som vil ha nytte av resynkroniseringsterapi 


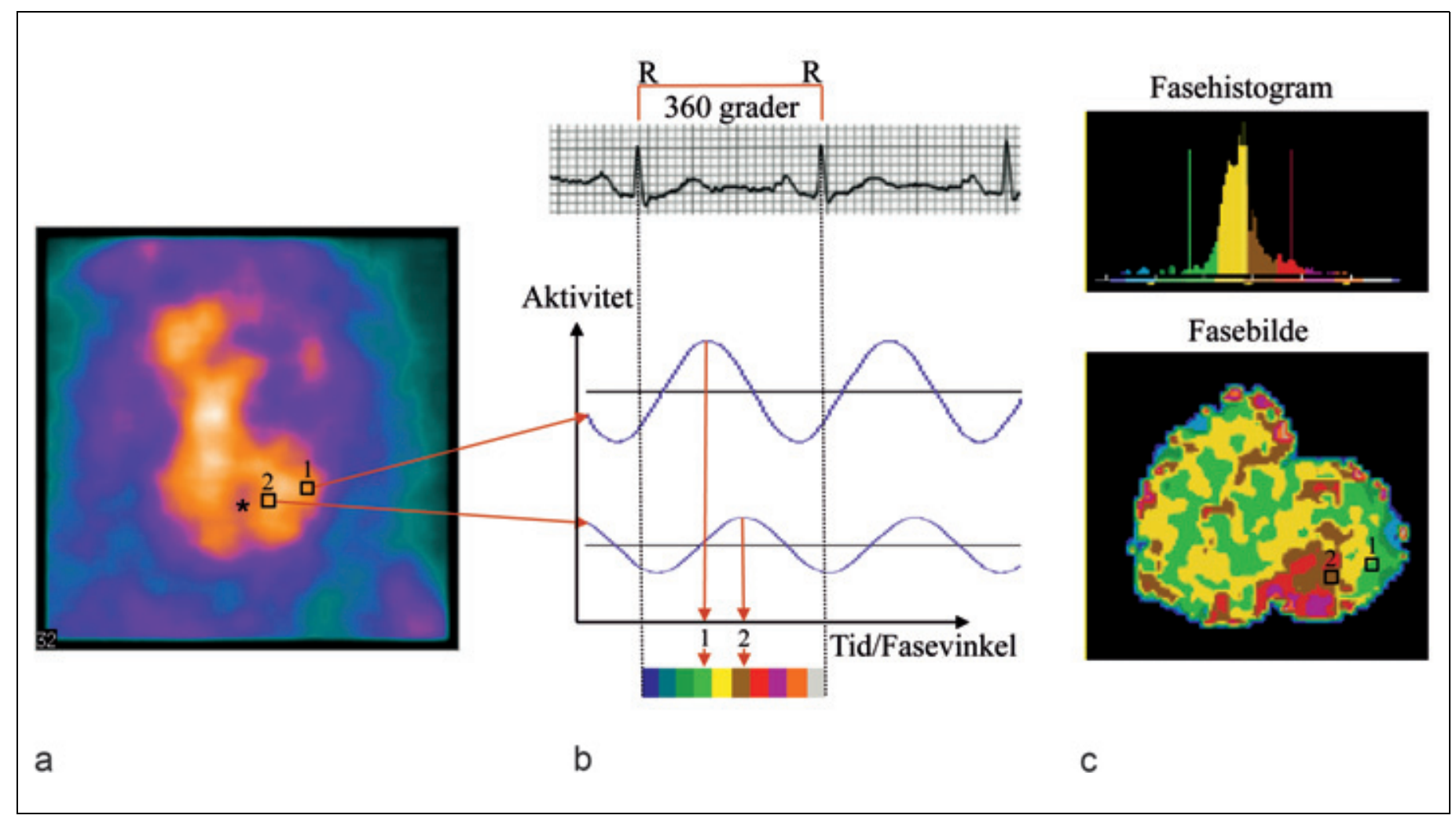

Figur 1 Illustrasjon av Fourier-transformasjon. al Rådata fra ${ }^{99 m} T c$-merkede erytrocytter hvor bildet viser hjertets aktivitetsoppladning i endediastolen. Det er godt skille mellom høyre og venstre ventrikkel (septum merket med *). For illustrasjonens skyld er to piksler i bildet avmerket som 1 og 2. b) Aktivitet-tidkurve viser hhv. piksel 1 og piksel 2 fra al som et periodisk signal med frekvens tilsvarende hjertefrekvensen. Samtlige piksler i bildet gjennomgår tilsvarende Fourier-transformasjon, der de periodiske signalene uttrykkes som en sum av sinus- og cosinusoscillasjoner. En hjertesyklus (R-R-intervallet) inndeles fra $0^{\circ}$ til 360 , og små gradsintervaller representeres med hver sin farge. Hver enkelt kurve gis en fargekode avhengig av kurvens bevegelsesmønster i tid. Eksemplet viser at piksel 1 og piksel 2 har samme periodisitet, men piksel 2 er forsinket sammenliknet med piksel 1 og representeres derfor med en annen fargekode enn piksel 1. c) Det genereres et fasebilde basert på hvilken fargekode hver enkelt piksel representerer. Bildet viser et område inferoapikalt som har et forsinket bevegelsesmønster $i$ forhold til resten av venstre ventrikkel. Deretter beregnes et fasehistogram som viser andelen piksler som beveger seg i samme fase

Tabell 2 Generelle karakteristika og resultat fra faseanalysen av pasienter inndelt etter kjønn og venstre ventrikkels ejeksjonsfraksjon

\begin{tabular}{|c|c|c|c|c|c|c|c|c|c|c|}
\hline & \multicolumn{10}{|c|}{ Venstre ventrikkels ejeksjonsfraksjon } \\
\hline & \multicolumn{2}{|c|}{55} & \multicolumn{2}{|c|}{$45-54$} & \multicolumn{2}{|c|}{$35-44$} & \multicolumn{2}{|c|}{$25-34$} & \multicolumn{2}{|c|}{$<25$} \\
\hline & $\begin{array}{l}\text { Menn } \\
\mathrm{n}=309\end{array}$ & $\begin{array}{c}\text { Kvinner } \\
\mathrm{n}=261\end{array}$ & $\begin{array}{l}\text { Menn } \\
n=180\end{array}$ & $\begin{array}{c}\text { Kvinner } \\
\mathrm{n}=60\end{array}$ & $\begin{array}{l}\text { Menn } \\
\mathrm{n}=158\end{array}$ & $\begin{array}{c}\text { Kvinner } \\
\mathrm{n}=43\end{array}$ & $\begin{array}{l}\text { Menn } \\
\mathrm{n}=134\end{array}$ & $\begin{array}{c}\text { Kvinner } \\
\mathrm{n}=38\end{array}$ & $\begin{array}{l}\text { Menn } \\
\mathrm{n}=75\end{array}$ & $\begin{array}{c}\text { Kvinner } \\
\mathrm{n}=8\end{array}$ \\
\hline Alder & 59 & 62 & 61 & 65 & 64 & 63 & 65 & 69 & 61 & 64 \\
\hline $\operatorname{LVEF}(\%)^{1}$ & 64 & 67 & 50 & 49 & 40 & 39 & 30 & 30 & 19 & 21 \\
\hline $\operatorname{RVEF}(\%)^{2}$ & 27 & 25 & 25 & 24 & 23 & 24 & 21 & 20 & 19 & 18 \\
\hline RR-int $(m s)^{3}$ & 915 & 848 & 915 & 817 & 880 & 809 & 797 & 750 & 773 & 740 \\
\hline Frekvens (/min) & 67 & 73 & 67 & 75 & 70 & 76 & 78 & 83 & 81 & 83 \\
\hline $\begin{array}{l}\text { F-mean LV (ms) } \\
\text { (antall grader) }\end{array}$ & $\begin{array}{c}404 \\
(160)\end{array}$ & $\begin{array}{l}386 \\
(166)\end{array}$ & $\begin{array}{c}418 \\
(166)\end{array}$ & $\begin{array}{l}394 \\
(175)\end{array}$ & $\begin{array}{c}416 \\
(172)\end{array}$ & $\begin{array}{c}390 \\
(174)\end{array}$ & $\begin{array}{c}396 \\
(181)\end{array}$ & $\begin{array}{c}371 \\
(179)\end{array}$ & $\begin{array}{l}394 \\
(185)\end{array}$ & $\begin{array}{c}374 \\
(181)\end{array}$ \\
\hline $\begin{array}{l}\text { F-SD LV (ms) } \\
\text { (antall grader) }^{5}\end{array}$ & $\begin{array}{l}56 \\
(21)\end{array}$ & $\begin{array}{c}51 \\
(21)\end{array}$ & $\begin{array}{c}75 \\
(29)\end{array}$ & $\begin{array}{l}73 \\
\text { (31) }\end{array}$ & $\begin{array}{l}88 \\
(35)\end{array}$ & $\begin{array}{c}85 \\
137)\end{array}$ & $\begin{array}{l}94 \\
(42)\end{array}$ & $\begin{array}{c}89 \\
(42)\end{array}$ & $\begin{array}{l}120 \\
(55)\end{array}$ & $\begin{array}{c}95 \\
(46)\end{array}$ \\
\hline $\begin{array}{l}\text { F-mean RV (ms) } \\
\text { (antall grader) }\end{array}$ & $\begin{array}{l}408 \\
(161)\end{array}$ & $\begin{array}{l}385 \\
(165)\end{array}$ & $\begin{array}{c}415 \\
(164)\end{array}$ & $\begin{array}{l}333 \\
(169)\end{array}$ & $\begin{array}{l}408 \\
(168)\end{array}$ & $\begin{array}{l}367 \\
(165)\end{array}$ & $\begin{array}{l}379 \\
(174)\end{array}$ & $\begin{array}{l}348 \\
(169)\end{array}$ & $\begin{array}{c}371 \\
(176)\end{array}$ & $\begin{array}{c}347 \\
(166)\end{array}$ \\
\hline $\begin{array}{l}\text { F-SD RV (ms) } \\
\text { (antall grader) }\end{array}$ & $\begin{array}{l}89 \\
\text { (34) }\end{array}$ & $\begin{array}{c}85 \\
(35)\end{array}$ & $\begin{array}{c}95 \\
(37)\end{array}$ & $\begin{array}{c}90 \\
(39)\end{array}$ & $\begin{array}{c}95 \\
(38)\end{array}$ & $\begin{array}{c}97 \\
(43)\end{array}$ & $\begin{array}{c}94 \\
(42)\end{array}$ & $\begin{array}{c}87 \\
(41)\end{array}$ & $\begin{array}{c}98 \\
(46)\end{array}$ & $\begin{array}{c}86 \\
(47)\end{array}$ \\
\hline $\begin{array}{l}\text { Diff RV-LV F-mean (ms) } \\
\text { lantall grader) }^{6}\end{array}$ & $\begin{array}{l}22 \\
(8)\end{array}$ & $\begin{array}{l}20 \\
(8)\end{array}$ & $\begin{array}{l}24 \\
\text { (9) }\end{array}$ & $\begin{array}{l}27 \\
(12)\end{array}$ & $\begin{array}{l}25 \\
(10)\end{array}$ & $\begin{array}{l}37 \\
(16)\end{array}$ & $\begin{array}{l}32 \\
(14)\end{array}$ & $\begin{array}{l}45 \\
(21)\end{array}$ & $\begin{array}{l}43 \\
(17)\end{array}$ & $\begin{array}{l}36 \\
(17)\end{array}$ \\
\hline
\end{tabular}

${ }^{1} \mathrm{LVEF}=$ venstre ventrikkels ejeksjonsfraksjon

${ }^{2} \mathrm{RVEF}=$ høyre ventrikkels ejeksjonsfraksjon

${ }^{3}$ RR-int $=$ R-til-R-intervall

${ }^{4} \mathrm{~F}-$ Mean $=$ fasevinklel midlet for venstre ventrikkel (LV) og høyre ventrikkel (RV)

${ }^{5} \mathrm{~F}-\mathrm{SD}=$ standardavvik for midlet fasevinkel for venstre ventrikkel (LV) og høyre ventrikkel (RV)

${ }^{6}$ Diff RV-LV F-mean = differanse $\mathrm{i}$ midlet fasevinkel mellom venstre ventrikkel (LV) og høyre ventrikkel (RV) 
som tidsreferansepunkt. Hver cosinuskurve karakteriseres med en faseverdi som representerer cosinusbølgens plassering i tid i forhold til R-takken på pasientens EKG. Grad av tidsforskyvning $\mathrm{i}$ et veggsegment innenfor et hjerteslag kan uttrykkes som fasevinkel eller i antall millisekunder. Et farget fasebilde med tilhørende histogram (fig 1c) fremstilles på bakgrunn av fasen til hver piksels cosinuskurve. Fargene i fasebildet representerer ventrikkelvegg som beveger seg synkront (i samme fase). Histogrammet viser andelen ventrikkelsegmenter som beveger seg i gitt fase, bredden på histogrammet gjenspeiler ventrikkelens evne til å slå synkront. Et breddeøkt histogram (stort standardavvik) vil derfor gi mistanke om dyssynkron bevegelse. Midlet fasevinkel fra $0^{\circ}$ til $360^{\circ}$ ble beregnet som den gjennomsnittlige fasevinkel for alle pikslene for henholdsvis venstre og høyre ventrikkelvegg (fig 2). Interventrikulær synkronitet ble vurdert ut fra differansen mellom midlet fasevinkel for høyre og venstre ventrikkelvegg. Intraventrikulær synkronitet for venstre ventrikkel ble vurdert i forhold til standardavviket av midlet fasevinkel for ventrikkelen.

Av de om lag 1500 ventrikulografier som er gjennomført i perioden 1998-2006 er det flere tilfeller av to eller flere undersøkelser av samme pasient. Pasientene er henvist fra kardiolog med anmodning om bestemmelse av venstre ventrikkels ejeksjonsfraksjon for videre oppfølging og behandling. Der det foreligger flere undersøkelser per pasient, er kun den første inkludert. Vi har utført en retrospektiv studie av totalt 1266 ventrikulografier, gjort hos 410 kvinner og 856 menn, og sett på sammenhengen mellom venstre ventrikkels ejeksjonsfraksjon og grad av intraog interventrikulær dyssynkronitet. Samtlige pasienter med ejeksjonsfraksjon $>55 \%$ som har vært under oppfølging $i$ perioden 1998-2006 i forbindelse med kardiotoksisk kreftbehandling, ble brukt for å etablere referanseverdier for intra- og interventrikulær fasevinkel for henholdsvis kvinner og menn. Referanseverdiene ble beregnet ut fra gjennomsnittet $\mathrm{i}$ normalfordelingene pluss to standardavvik. På grunnlag av referanseverdiene registrerte vi andelen av de 1266 ventrikulografiene som befant seg i det patologiske området og grupperte dem i intervaller basert på venstre ventrikkels ejeksjonsfraksjon. Resultatene ble bearbeidet i Exel regneark. Det ble brukt t-test for å se etter signifikante forskjeller i alder kjønnene imellom, forskjeller i alder mellom de ulike LVEF-intervallene samt kjønnsforskjeller i standardavvik for midlet faseverdi i de ulike intervallene av venstre ventrikkels ejeksjonsfraksjon. Signifikansnivået ble satt til $\mathrm{p}<0,05$. Studien er godkjent av regional komité for medisinsk forskningsetikk, Nord-Norge.

\section{Resultater}

Tabell 2 viser generelle karakteristika og resultater av faseanalysen der pasientene er
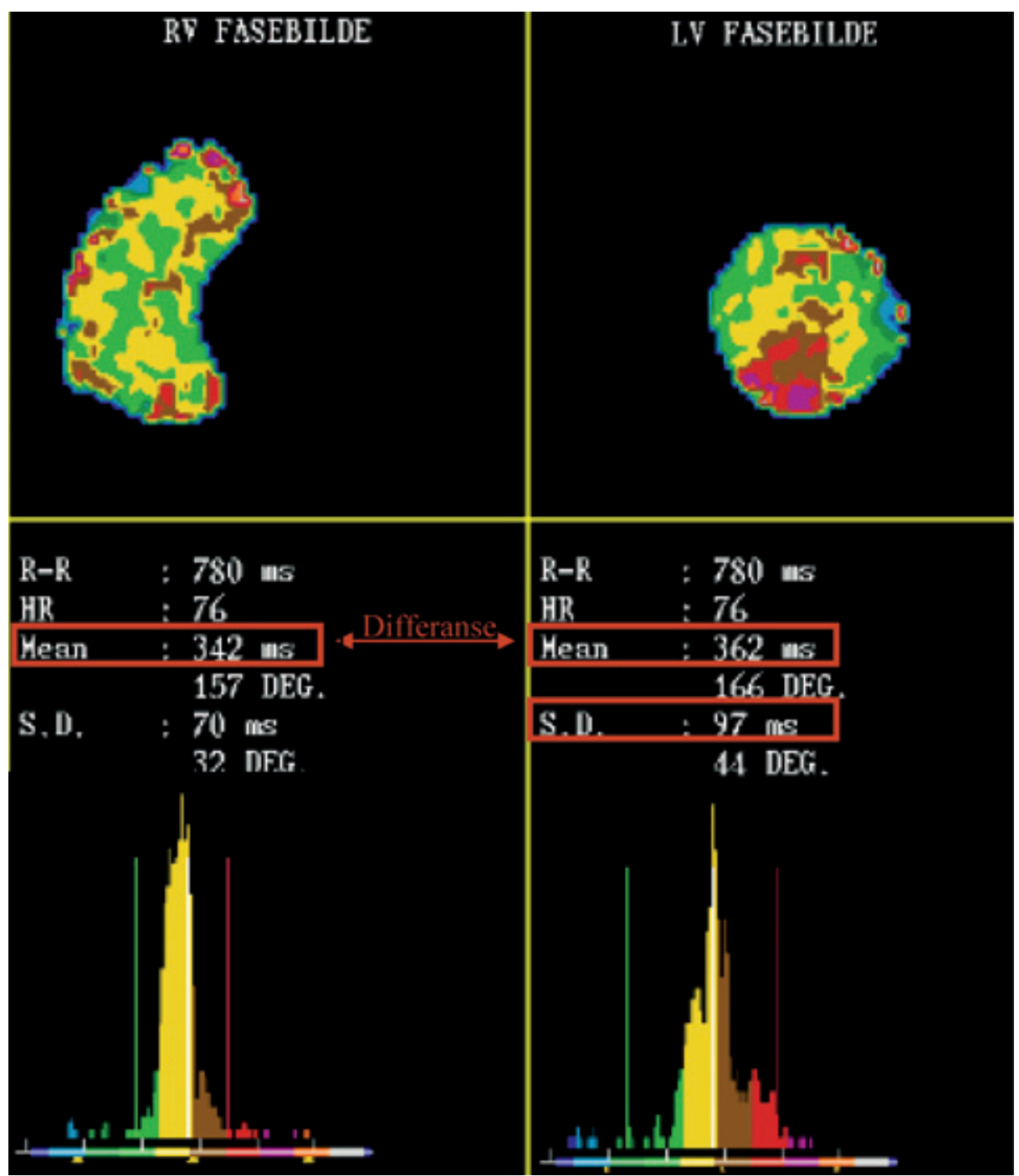

Figur 2 Fasebilde med tilhørende verdier og histogram for hhv. høyre ventrikkel (RV) og venstre ventrikkel (LV). Fasebildet viser et område inferoapikalt i venstre ventrikkel som har forsinket sammentrekning og hvor tilhørende histogram er tydelig breddeøkt. Standardavviket ( $44^{\circ}$ eller $97 \mathrm{~ms}$ ) indikerer intraventrikulær dyssynkronitet, da verdiene ligger over øvre grenseverdi $\left(33^{\circ}\right.$ eller $\left.71 \mathrm{~ms}\right)$. Det foreligger ikke interventrikulær dyssynkronitet, da differansen mellom midlet fasevinkel for høyre og venstre ventrikkel $19^{\circ}$ eller $\left.20 \mathrm{~ms}\right)$ ikke er utenfor øvre grenseverdi $\left(15^{\circ}\right.$ eller $\left.34 \mathrm{~ms}\right)$

inndelt etter kjønn og venstre ventrikkels ejeksjonsfraksjon. Det foreligger ingen signifikant aldersforskjell mellom menn og kvinner eller mellom de ulike LVEF-intervallene for henholdsvis menn og kvinner. Midlet alder i de ulike intervallene varierer fra 62 år til 69 år for kvinner og fra 59 år til 65 år for menn. Det er en tendens til økende hjertefrekvens med synkende venstre ventrikkels ejeksjonsfraksjon hos begge kjønn, og det ser ut til at kvinnene ligger noe høyere $i$ frekvens enn mennene i tilsvarende intervall. Vi observerte ingen kjønnsforskjeller i standardavviket for midlet faseverdi, som representerer grad av intraventrikulær synkronitet, i de ulike intervallene.

Referanseverdiene for intra- og interventrikulær synkronitet, beregnet ut fra normalfordelingen for kvinner og menn, er presentert i tabell 3. Standardavviket for midlet

Tabell 3 Normalfordelingsmateriale med referanseverdier for intra- og interventrikulær synkronitet

$\begin{array}{ccccll}\text { Kjønn } & \text { Antall } & \text { Alder lår) } & \begin{array}{c}\text { Venstre ventrikkels } \\ \text { ejeksjonsfrakjon (\%) }\end{array} & \begin{array}{l}\text { Intraventrikulær } \\ \text { grenseverdi }\end{array} & \text { Interventrikulær } \\ \text { grenseverdi }\end{array}$




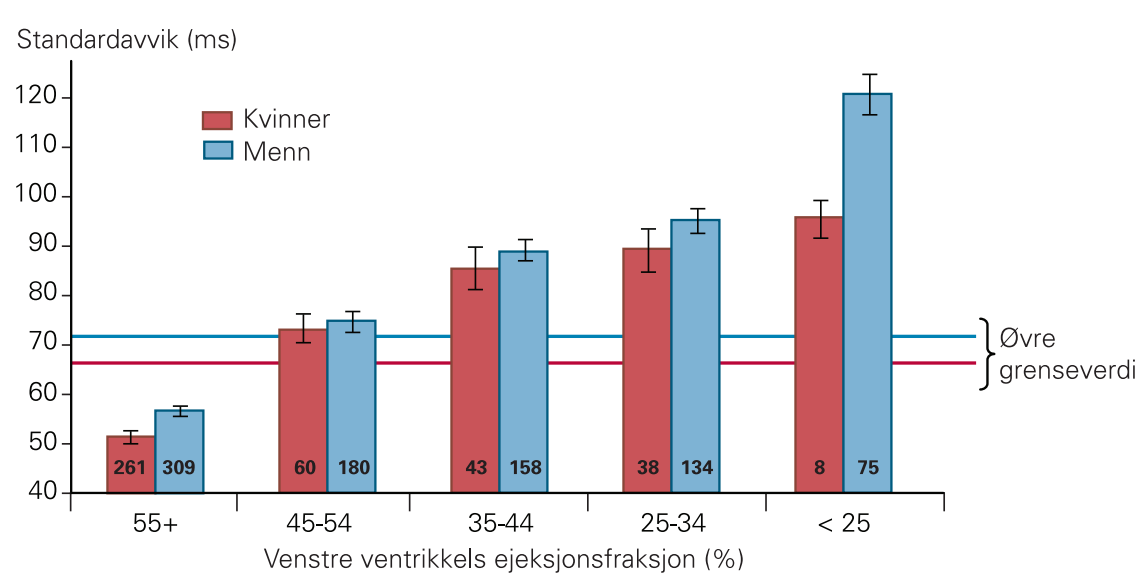

Figur 3 Sammenhengen mellom venstre ventrikkels ejeksjonsfraksjon og intraventrikulær dyssynkronitet. Stolpediagrammet viser gjennomsnittlig standardavvik (SD) for venstre ventrikkels fasevinkel for kvinner (rød) og menn (blå) i ulike intervaller for venstre ventrikkels ejeksjonsfraksjon. Hos begge kjønn er det en økende tendens til intraventrikulær dyssynkronitet med synkende ejeksjonsfraksjon i venstre ventrikkel. Rød og blå horisontal linje indikerer øvre grenseverdier for synkronitet for hhv. kvinner og menn. Tallene i kolonnene representerer antall pasienter. Avvikene i stolpediagrammet representerer standardfeil for gjennomsnittet (SEM)

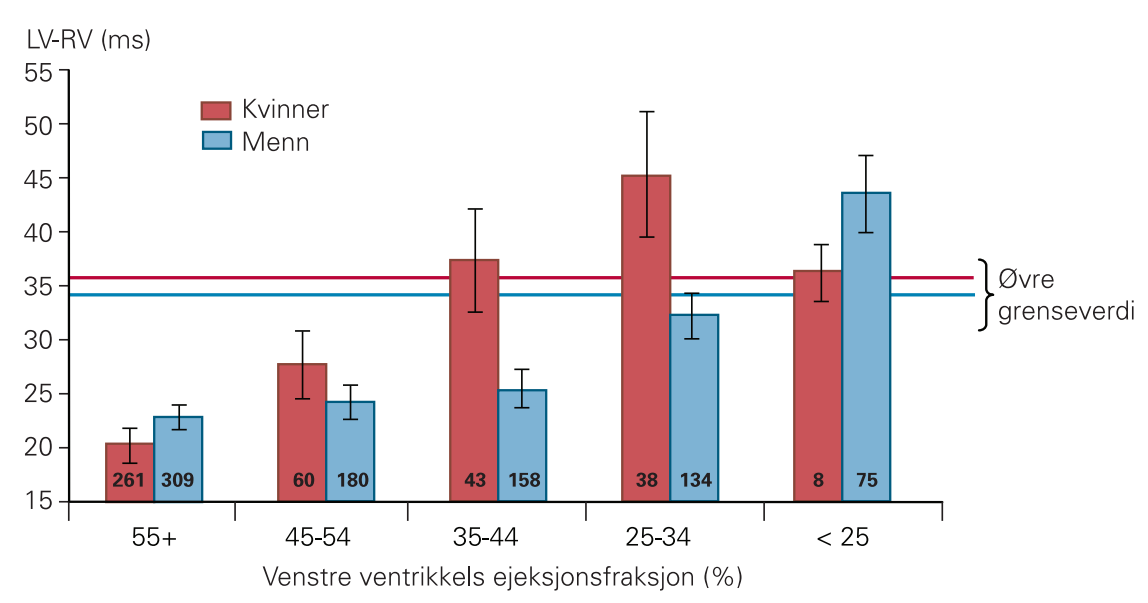

Figur 4 Sammenhengen mellom venstre ventrikkels ejeksjonsfraksjon og interventrikulær dyssynkronitet. Stolpediagrammet viser gjennomsnittlig differanse mellom midlet fase for høyre og venstre ventrikkel. Hos begge kjønn er det økende tendens til interventrikulær dyssynkronitet med synkende ejeksjonsfraksjon i venstre ventrikkel. Rød og blå horisontal linje indikerer øvre grenseverdier for synkronitet for hhv. kvinner og menn. Tallene i kolonnene representerer antall pasienter. Avvikene i stolpediagrammet representerer standardfeil for gjennomsnittet (SEM)

Tabell 4 Antall pasienter med dyssynkronitet

\begin{tabular}{|c|c|c|c|c|}
\hline & & $\begin{array}{l}\text { Intra- og inter- } \\
\text { ventrikulær } \\
\text { dyssynkronitet }\end{array}$ & $\begin{array}{l}\text { Interventri- } \\
\text { kulær dys- } \\
\text { synkronitet }\end{array}$ & $\begin{array}{l}\text { Intraventri- } \\
\text { kulær dys- } \\
\text { synkronitet }\end{array}$ \\
\hline \multirow[t]{2}{*}{ Ejeksjonsfraksjon $\geq 55$} & Menn $n=309$ & 20 & 57 & 65 \\
\hline & Kvinner $n=261$ & 6 & 34 & 39 \\
\hline \multirow[t]{2}{*}{ Ejeksjonsfraksjon 45-54 } & Menn $n=180$ & 23 & 45 & 85 \\
\hline & Kvinner $\mathrm{n}=60$ & 10 & 15 & 32 \\
\hline \multirow[t]{2}{*}{ Ejeksjonsfraksjon 35-44 } & Menn $n=158$ & 34 & 41 & 116 \\
\hline & Kvinner $n=43$ & 17 & 20 & 28 \\
\hline \multirow[t]{2}{*}{ Ejeksojnsfraksjon 25-34 } & Menn $n=134$ & 43 & 53 & 103 \\
\hline & Kvinner $\mathrm{n}=38$ & 12 & 19 & 25 \\
\hline \multirow[t]{2}{*}{ Ejeksjonsfraksjon < 25} & Menn $n=75$ & 29 & 31 & 70 \\
\hline & Kvinner $\mathrm{n}=8$ & 4 & 4 & 8 \\
\hline
\end{tabular}

faseverdi for venstre ventrikkel under $67 \mathrm{~ms}$ og $71 \mathrm{~ms}$ for henholdsvis kvinner og menn tilhører normalområdet for intraventrikulær synkronitet $i$ vår studie. Tilsvarende beregnet vi normalområdet til differansen mellom midlet faseverdi for høyre og venstre ventrikkel, interventrikulær synkronitet, til mindre enn $36 \mathrm{~ms}$ og $34 \mathrm{~ms}$ for henholdsvis kvinner og menn. Det er en klar tendens til økende dyssynkronitet ved fallende venstre ventrikkels ejeksjonsfraksjon for både kvinner og menn (fig 3, fig 4). Med synkende venstre ventrikkels ejeksjonsfraksjon øker andelen som befinner seg utenfor normalområdet for både inter- og intra- ventrikulær synkronitet (fig 5). For kvinner og menn med venstre ventrikkels ejeksjonsfraksjon under $35 \%$ er det henholdsvis $35 \%$ og $34 \%$ som har både inter- og intraventrikulær dyssynkronitet (tab 4).

\section{Diskusjon}

Resynkroniseringsterapi er en nylig etablert behandlingsform for pasienter med alvorlig grad av hjertesvikt. Elektromekanisk forsinkelse resulterer i dyssynkron kontraksjon av venstre ventrikkel (intraventrikulær dyssynkronitet) og mellom venstre og høyre ventrikkel (interventrikulær dyssynkronitet). Kliniske studier viser at hos en av tre som har gjennomgått resynkroniseringsterapi uteblir bedringen. Seleksjon av egnede kandidater blant hjertesviktpasientene til resynkroniseringsterapi er derfor en utfordring.

Det kan være flere årsaker til at $30 \%$ av dem som gjennomgår resynkroniseringsterapi ikke responderer. Feil plassering av pacemakerledningen $i$ laterale vegg av venstre ventrikkel der ledningen sitter i koronarvenen og der veneanatomien ikke alltid er optimal, vil medføre suboptimale stimuleringsforhold. En annen mulig årsak til at en høy andel av pasientene ikke responderer kan skyldes seleksjonskriteriet med breddeøkt QRS-kompleks som indikator på elektromekanisk forsinkelse. QRS-varigheten har vist seg å være en dårlig markør for dyssynkronitet for pasienter med hjertesvikt. Hos $30 \%$ av dem med breddeøkt QRS-kompleks er det ikke noen intraventrikulær dyssynkronitet av betydning. I tillegg viser det seg at $30 \%$ av dem med smale QRS-komplekser har intraventrikulær dyssynkronitet $(7,8)$. En tredje årsak kan være ikke-viabelt myokard i området rundt pacemakerledningen $(9,10)$. Transmuralt arrvev rundt venstre ventrikkels pacemakerledning kan hindre ønsket respons. Evaluering av viabilitet og arrvev bør tas i betraktning i seleksjonsprosessen før implantering av biventrikulær pacemaker (6).

Det er en klar tendens til økende intra- og interventrikulær dyssynkronitet ved fallende venstre ventrikkels ejeksjonsfraksjon for både kvinner og menn (fig 3, fig 4). I vår studie finner vi at $35 \%$ av kvinnene og $34 \%$ av mennene med venstre ventrikkels ejeksjonsfraksjon $<35 \%$ har både intra- og interven- 


\section{Kvinner}

Andel pasienter med dyssynkronitet (\%)

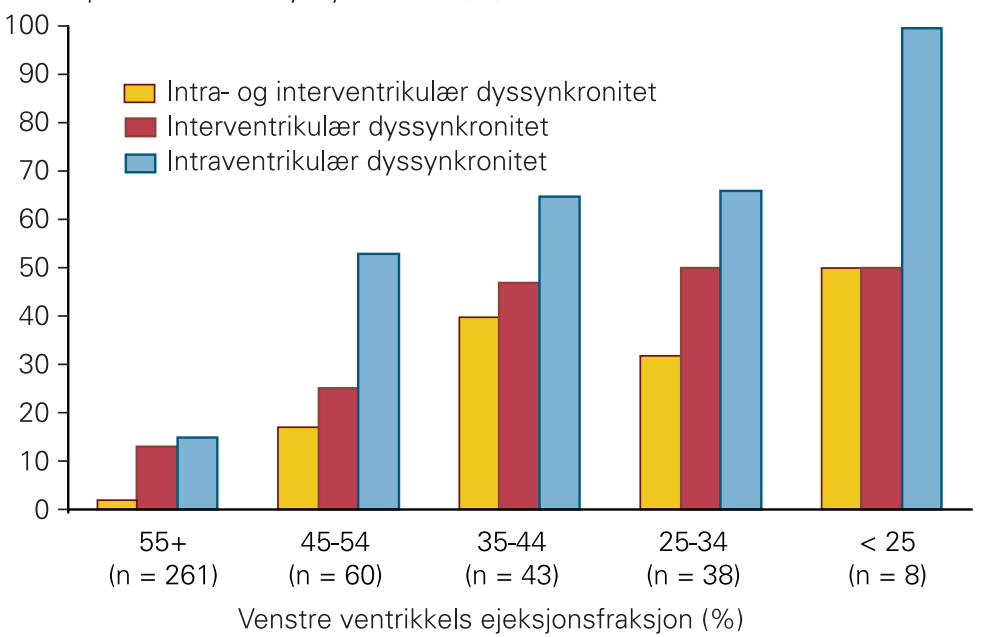

Menn

Andel pasienter med dyssynkronitet (\%)

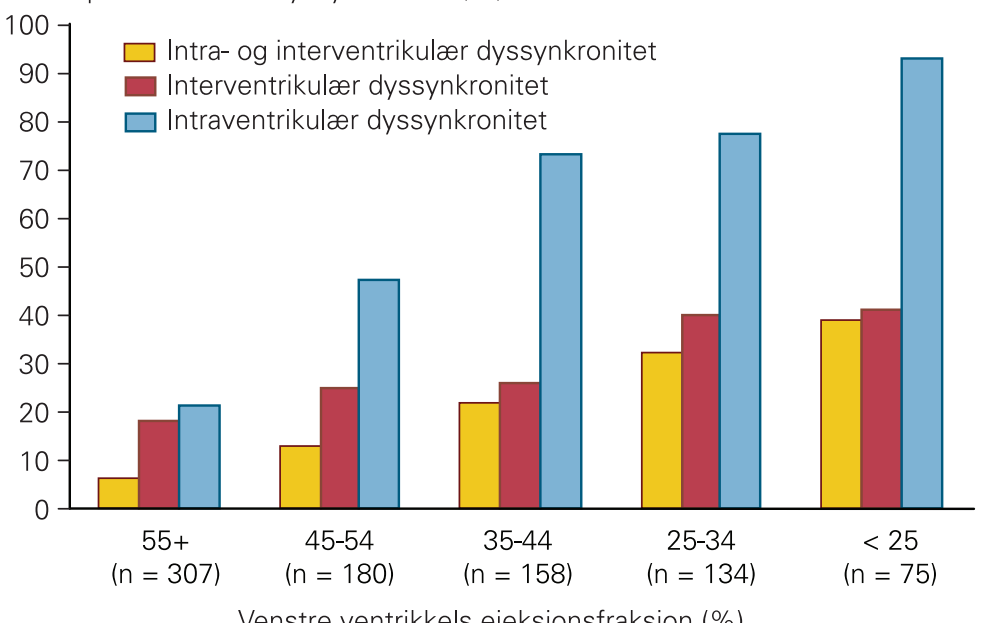

Venstre ventrikkels ejeksjonsfraksjon (\%)

Figur 5 Stolpediagram som viser andelen pasienter i de ulike intervaller av venstre ventrikkels ejeksjonsfraksjon som har intraventrikulær (blå), interventrikulær (rød) og både intra- og interventrikulær (gul) dyssynkronitet for kvinner (øvre diagram) og menn (nedre diagram). Totalt antall undersøkte pasienter $i$ de ulike intervallene er angitt i parentes

trikulær dyssynkronitet (tab 4). I samme pasientgruppe var det for kvinner og menn henholdsvis $13 \%$ og $11 \%$ med synkron kontraksjon. Det var ingen signifikant aldersforskjell mellom de ulike LVEF-gruppene ( $\operatorname{tab} 2)$. Ved å benytte ventrikulografi med faseanalyse oppnås et kvantitativt mål på det er sammenheng mellom respondere (bedring i NYHA-klasse) og bedring i dyssynkronitet. I så fall kan dyssynkronitet bli et aktuelt tilleggskriterium for å selektere pasienter til resynkroniseringsterapi.

Ingebjørg Larsen og Hanne Marie Weydahl har bidratt like mye til denne artikkelen.

Vi takker bioingeniør Torbjørn Jakobsen Fredenfeldt for teknisk assistanse og Eivind S.P. Myhre og Kirsti Ytrehus for gjennomlesing av manuskriptet.

Oppgitte interessekonflikter: Ingen

\section{Litteratur}

1. Cleland JG, Daubert JC, Erdmann E et al. Longerterm effects of cardiac resynchronization therapy on mortality in heart failure [The Cardian REsynchronization-Heart Failure (CARE-HF) trial extension phase]. Eur Heart J 2006; 16: 1928-32.

2. Cleland JG, Daubert JC, Erdmann E et al. The effect of cardiac resynchronization on morbidity and mortality in heart failure. N Engl J Med 2005; 15: $1539-49$

3. Abraham WT, Fisher WG, Smith AL et al. Cardiac resynchronization in chronic heart failure. $\mathrm{N}$ Engl J Med 2002; 346: 1845-53.

4. Muramatsu T, Matsumoto K, Nishimura S. Efficacy of the phase images in Fourier analysis using gated cardiac POOL-SPECT for determining the indication for cardiac resynchronization therapy. Circ J 2005; 69: 1521-6.

5. O'Connell JW, Schreck C, Moles M et al. A unique method by which to quantitate synchrony with equilibrium radionuclide angiography. J Nucl Cardiol 2005: 12: 441-50.

6. Fauchier L, Marie O, Casset-Senon D et al. Interventricular and intraventricular dyssynchrony in idiopathic dilated cardiomyopathy. A prognosis study with Fourier phase analysis of radionuclide angioscintigraphy. J Am Coll Cardiol 2002; 40: 2022-30.

7. Yu CM, Lin H, Sanderson JE. High prevalence of left ventricular systolic and diastolic asynchrony in patients with congestive heart failure and normal QRS duration. Heart 2003; 89: 54-60.

8. Ghio S, Constantin C, Klersy C et al. Interventricular and intraventricular dyssynchrony are common in heart failure patients, regardless QRS duration. Eur Heart J 2004; 25: 571-8.

9. Conti CR. Cardiac resynchronization therapy for chronic heart failure: why does it not always work? Clin Cardiol 2006; 29: 335-6.

10. Ypenburg C, Schalij MJ, Bleeker GB et al. Impact of viability and scar tissue on response to cardiac resynchronization therapy in ischaemic heart failure patients. Eur Heart J 2007; 28: 33-41.

både intra- og interventrikulær dyssynkronitet. De pasientene som befinner seg innenfor referanseområdet vil mest sannsynlig ikke være egnet for resynkroniseringsterapi. Det er nødvendig med videre studier for å sammenlikne ventrikulografier til pasienter før og etter resynkroniseringsterapi for å se om
Manuskriptet ble mottatt 30.3. 2007 og godkjent 16.5. 2008. Medisinsk redaktør Siri Lunde. 